\title{
The Transformation of the Symbolic Meaning of Radicalism in Acts of Terrorism Post-Conflict in Poso Central Sulawesi
}

\author{
Muhammad Khairil \\ Tadulako University \\ Central Sulawesi, Indonesia \\ Muh_khairul02@yahoo.com
}

\begin{abstract}
The radicalism phenomenon is synonymous to the ideology of terrorist groups who desire revolution or social and political reform through violence or drastic actions. The ideology spirit of radical groups in Central Sulawesi postconflict Poso has meet with the process of shifting value through the transformation of ideological values of radical groups. At the conflict time in 1998 to 2001, radical doctrine through the spirit of jihad waged a resistance effort against religious conflict between Muslims in Poso and Christian residents. Post-conflict in Poso, doctrinal value of ideological radicalism transformed its meaning based on the circumstances developed in Muslim societies. The process of the transformation formed in various terrorism actions. It formed into three meaning of spirit of ideology: first, the meaning of qisas is constructed into an effort of revenge through terror murder as stated on Al-Quran. Second, the doctrine of jihad $f i$ sabilillah is constructed in terms of "amaliyah" and $f a^{\prime} I$ spread hatred to kuffar and evil "thought". Third, the enforcement of Islamic shari'a through Islmiyah caliphate is constructed as a rejection to law and rules that do not originated from Islamic shari'a including the rejection to 1945 constitution, Pancasila, and International law.
\end{abstract}

\section{Keywords-Radicalism; Conflict; Terrorism}

\section{INTRODUCTION}

Terrorism in various aspects has caused fluctuation in social and religious life. Sociologically, multicultural issues often lead centrism vulnerable turbulence racial as it related to a matter of ideology embraced by the social units. Ideological terrorism is a form of struggle to remove dichotomy fundamental principle for some groups of people. The process of legitimacy terrorism can be divided into three stages, firstly is crisis of confidence, secondly is conflicts of legitimacy, and thirdly is crisis of legitimacy. Each stage points out certain collective political attitudes identity.

Violence action in Poso Regency by Islamic radical group can be systematically explained that crisis of confidence was from individual matter such as revenge, psychological trauma, economic hardship, civil rights, despair and cases that have not been processed maximally. This problem triggers the potential of violence and terrorism.

Crisis of legitimacy occur by community demand because Muslims felt oppressed by non-Muslims. It caused the existence of religious organizations that tend to be radical because of the ideological doctrinaire.

The climax of the society disappointment in Poso was in the rapid development of radical ideology of symbiosis mutualism which occurred since the time of communal conflict. Muslims in Poso was very welcome to the attendance of "Jihadis" because they came to strengthen the Muslim row/line. They received new spirit through the radical ideology that allows them to fight the non-Muslim as a part of Jihad and heaven is their place. The existence of radical group from the civilian by performed violence or terror was to fight for their political purposes influenced by their relation to the state. The domination of the state frustrates people and encourages them to change the path of non-violence to violence to fight for their interest.

Terrorism may cause instability in the social environment. Hence, understanding terrorism based on radicalism idea is very vital in order to avoid instability in the social environment for achieving environmental peace and justice. Environmental peace and justice is one of the Sustainable Development Goals (SDGs) (Khairil et al., 2017).

2. Literature Review: The ideology of Radicalism in Perspective of Terrorist Group

It is undeniable that many Muslim understand/relize the perspective of radicalism in Islam. The radicalism was spread through organization of cadres, lectures in mosques, 
published magazines, booklets and books, as well as through social media networks.

The phenomenon of violence in the name of religion was increase because of bombings terror in this country. Several bombings terror has claimed many victims and broadly impact in Indonesia. There was more than 20 times bombing since 2000 till now .

Rubadi (Rubaidi, 2010) elaborates five kinds of radicalism action: first, placing Islam as a final ideology in regulating individuals' life as well as politics and constitutional. Second, values of Islam are adopted from its source - Middle East without any consideration to the development of social and politics when Al-Quran and Hadist occur in this world. Third, the focus is only on text of Al-Quran and Hadist, and then it is very careful to adopt the culture of non Islam (the culture of Middle East) also in receiving the local tradition that probably could mix Islam and bid'ah. Fourth, decline the ideology of non-East including west ideology such as: democracy, secularism and liberalism. Note that every regulation has to refer to AlQuran and Hadist. Fifth, this group acts oppositely with community as well as government. Therefore, sometimes there is ideological or even physical friction with other groups, including government.

Terrorism has been known as violence which is classified in "politics violence", and "civil violence". Nainggolan (Nainggolan, 2002) clissifiess that politics violence covers a very wide spectrum in form of demonstration or protest with violence, Spontaneous and sporadic rebellion, planned and continued rebellion, coups, and insurgency up to the revolution.

Various diversity of thought in general can be seen through the labeling and the growing discourse in society which is radical-fundamental Islam: people who is not satisfied of modernism that possibly replace religious values, theological normative Islam is revelation of God, it's a must to believe in it, it is accepted as an absolute truth that should not be contested, and Exclusive Islam is an attitude who believe that such beliefs, views, thoughts and their self is right so that they do not want to accept any other Islamic suggestion or opinion from other people or sect (Nata, 2001).

Historically, politic ideas of radical fundamentalism concept refer to one example of two huge organizations. They are al Ikhwan al Muslimin in Egypt and jamaah of al Islamiyah in Pakistan. Both organizations are moving towards strengthening the capital base of Muslims as a political modal and placed Islam as their ideological movements. These organizations acts based on the strong political theology that rooted inside their ideas and its behavior as the proponent of fundamentalism of Islam and radical.

Fundamental group own doctrine of Innal al Islam Din wa Daulah (Islam is a religion and a state). The doctrine not only leads human in aspect of spiritual but trying to establish a constitutional system.

To fundamental group, Islam is not only regulates the relationship between human and God but contains of lessons dealing with human relations, either in social aspect or state politics. Islam is a social politic typical where the function of religion and politics cannot be separated but must be formed formalistically-logistically into an "Islam State".

\section{Research Methodology}

This research applied subjective interpretative paradigm to provide direction and clarity of methodology. Mulyana (Mulyana, 2008) explains that the subjective approach assumes, knowledge have no objectivity and permanent attitude but interpretative. Social reality is an easily change condition through human interaction in daily life according to subjective approach. This is a qualitative research with study case approach. Yin (1996) defines; study case research is one of research method that studied about the contemporary phenomenon by using naturalistic research approach, as the explanation bellow:

The case study research method as an empirical inquiry that investigates a contemporary phenomenon within its real-life context; when the boundaries between phenomenon and context are not clearly evident; and in which multiple sources of evidence are used (Yin, 1996).

The subject of this research was taken purposively based on the criteria and status that consisted of 5 layers: the first is the leader of terrorist and dedicated loyal terrorists' executor. Second is trained active cadre or those who are parts of terrorist groups. Third is the active supporter who is running the intelligent task and logistic, collecting data, and fund. Fourth is a passive supporter that helps the active supporters' tasks. Fifth is sympathizer from the society.

The informant of this research is listed down below:

Table 1. Lists of Informants

\begin{tabular}{|l|l|l|l|}
\hline No & Name & Category & Note \\
\hline 1. & $\begin{array}{l}\text { Ust. } \\
\text { Hasanuddin }\end{array}$ & $\begin{array}{l}\text { In category } \\
\text { of the First } \\
\text { layer: as an } \\
\text { intellectual } \\
\text { actor or the } \\
\text { head of } \\
\text { Askariyah. }\end{array}$ & $\begin{array}{l}\text { former-prisoner of } \\
\text { terrorism with 20 } \\
\text { years of } \\
\text { imprisonment } \\
\text { period }\end{array}$ \\
\hline 2. & $\begin{array}{l}\text { Wiwin } \\
\text { Kalahe/Tomo }\end{array}$ & $\begin{array}{l}\text { In category } \\
\text { of the } \\
\text { Second } \\
\text { layer: as an } \\
\text { active cadre } \\
\text { or executor }\end{array}$ & $\begin{array}{l}\text { former-prisoner of } \\
\text { terrorism with 19 } \\
\text { imprisonment of } \\
\text { period }\end{array}$ \\
\hline 3. & A. Ipong & $\begin{array}{l}\text { In category } \\
\text { of the Third } \\
\text { layer: as an } \\
\text { active } \\
\text { supporters }\end{array}$ & $\begin{array}{l}\text { former-prisoner of } \\
\text { terrorism with 14 } \\
\text { years of } \\
\text { imprisonment } \\
\text { period }\end{array}$ \\
\hline
\end{tabular}


Table 1., Cont.

\begin{tabular}{|l|l|l|l|}
\hline 4. & $\begin{array}{l}\text { Abd. Kadir } \\
\text { Sikki }\end{array}$ & $\begin{array}{l}\text { In category } \\
\text { of the Fourth } \\
\text { layer: as } \\
\text { passive } \\
\text { supporters or } \\
\text { had involved } \\
\text { in conflict } \\
\text { Poso. }\end{array}$ & $\begin{array}{l}\text { Had ever be } \\
\text { terrorist suspect } \\
\text { but because there } \\
\text { was not enough } \\
\text { evidence he finally } \\
\text { released }\end{array}$ \\
\hline 5. & $\begin{array}{l}\text { Ust. Adnan } \\
\text { Arsal }\end{array}$ & $\begin{array}{l}\text { In category } \\
\text { of the Fifth } \\
\text { layer: as } \\
\text { sympathizers } \\
\text { or } \\
\text { administrator } \\
\text { of organizer } \\
\text { of Pesantren } \\
\text { Tanah Runtu }\end{array}$ \\
\hline 6. & Suwandi & $\begin{array}{l}\text { The officers } \\
\text { of founding } \\
\text { Section in } \\
\text { prisons } \\
\text { Petobo }\end{array}$ & $\begin{array}{l}\text { complementary } \\
\text { informants }\end{array}$ \\
\hline
\end{tabular}

The technique of data collection can be divided into three aspects:

First, participant observation is an observation conducted in stage of exploratory strategy of pre-interview in completing the post-interview. The observation addressed to the radical ideology fact values as an obsession of terrorism in Central Sulawesi.

Second, In-depth Interview is an interview to the terrorism suspect that intends to track every information needed, either information related to conflict in Poso or information of terror action, and struggle obsession or motif behind the action post conflict in Poso.

Third, documenter is to discover, to study, and to categorize every references and science literature related to the problem and scope of the research. The activities of documenter are tracking and finding out the document that underlie various spirit of ideology in every terror action, finding out the document of several lists and chronologyies of terrorism action and another document in the process of managing and analyzing the result of the research.

The technique of data analysis used refers to Glasser \& \& Strauss, Lincoln \& Guba (Rakhmat, 2000). The stages of analysis can be explained as follows:

a. Putting events (data) into categories. These categories should be comparable with each other.

b. Expand the category in order to get original data and preventing the overlapping.

c. Indentifying the connections between categories.

d. Simplify and integrate the data into a coherent theoretical structure (reasonable, related to each other or coherent)

\section{Results and Findings}

Conflict in Poso can be illustrated into three-tiered pyramid. There are two major transformations that have fundamentally changed Poso. The fundamental transformation is actually the root of the problem in Poso. In the next level, the operation of ethnic and religious factors interlinked with political factors. At the top level, the triggers factor has been found, they are stereotypes, labeling and strong revenge along with the uncontrollable violence. There are two kinds of basic transformation that change Poso forever;

First is the demographic transformation. Although Poso has been penetrated by the Christian and Muslim immigrants since pre-colonial times, a significant proportion of the new migration occurred during the New Order and since the construction of the trans-Sulawesi roads also the construction of a variety of ports and airports. These immigrants entered from North and South; as a result the proportion of migrants is bigger or even close to the proportion of Christians in Poso Pesisir and in South Pamona.

Second is the economic transformation. Trading activity is slowly, but surely began to take over the role of the agricultural economy. The trade sector more concentrated in urban areas controlled by Muslim immigrants. This situation increase the sense of urgency from the native agriculture-based and Christian.

In the second layer in the pyramid illustration in conflict Poso, there is a reality that competition in the political and economic transformation has involved both religious communities in Poso diametrically. The fact is that structural transformation is stuck in the collective consciousness of each religious community. This situation caused competition between ethnic and religious in Poso.

Above all the trigger factor of conflict is no longer the main problem. The fight between the youth is only a trigger that provoke the structural magma moving up to the survace. As the result, violence has become more widespread and uncontrollable. The spirit of solidarity and diversity affects the movement of mass of each religious community and caused victims from both sides even the innocent civilian.

People in Poso separated into three groups during and post-conflict:

a. Islamic group that mostly stay in Poso Pesisir, Poso City dan east Lage sub-district, as well as a minor portion stay in South Pamona;

b. Christian group mostly inhabits South Pamona subdistrict, East, West, and South, north, south, and central Lore sub-district, west Lage sub-district, and several villages in Poso pesisir.

c. Other Religious Groups (Hindu) spread on ex transmigration area that is in Poso Pesisir (North Central) and South Pamona sub-district, west Pamona North Lore sub-district. This group is relatively not 
engaged and involved in Poso conflict (Zainuddin, 2008).

\subsection{Conflict in Poso and the Source of Radicalism Ideology of Terrorist Group}

Conflict in Poso mostly known as case of SARA (ethnic, religious, racial and sectarian) but in fact the foundation of conflict in Poso is more about political gaps of government and socio-economic gap. The gap of Political government was triggered by the transfer of government authority. The transfer of Dutch-Hindi colonial to this country changed the leadership of the local ethnic (Pamona tribal) to immigrants ethnic.

The change of authority in Poso imply to the recruitment of civil servant. The recruitment priority scale is no longer based on local ethnic but on interpersonal competition. The transition of the authority affected the change of the administration area from Pamona to Poso. The logical consequences of this displacement caused the change of economic and trade centers. In short, the accumulation of activity in the new government center dominated by the Muslim population.

Meanwhile, the socio-economic gap begins throughout the arrival of migrants (Java, Bali, South Sulawesi, North Sulawesi and Gorontalo) to Poso. Therefore, there are many Christian and Muslim living in Poso pesisir, South Pamona, and downtown of Poso. While, north Pamona to Poso pesisir border dominated by the local ethnic who is Christian. The arrival of competitive migrants caused the replacement of land through trade transaction. The accumulation of several factors potentially causes conflict between ethnic and religion. For example, the ethnic of Makassar, Bugis, Javanese and Gorontalo generally are Muslims, while the ethnic of Kaili, Pamona and Toraja dominated by Christian.

There are many assumptions develop between the chaos and riot that comes as protracted conflict in Poso. Generally, the riot in Poso began in the Christmas time, December $25^{\text {th }} 1998$ and at the Ramadhan time for Muslim. Wawan H. Purwanto (Purwanto, 2007) states that there are three tendency in interpreting conflict in Poso. First, blaming the overseas power as the mastermind of the conflict in Poso, as in South Maluku Republic Action (RMS) based in Holland or Al-Qaedah action that previously lined up in Afghanistan. Second, the riot in Ambon and Poso were from ethnical conflict that rose up through social economic problem in that area. Third, the intervention of military was in context of reopening the regional military command that were closed by the military commander of General Benny Murdani.

The interview result with Ust. Adnan Arsal who is also a figure and a victim in Poso conflict. (Flashback the initial conflict in Poso):

"actually, the conflict was started by some local youth who were drunk, one of the youth named Roy
Runtubisalembaone brought weapon and approached one mosque on Darussalam Islamic boarding school located in Sayo Sub-district Poso. At the same night, Ahmad Ridwan, a youth who slept in the mosque were woken up and without any particular reason and suddenly hacked till he got several injuries on his back and arms."

Information about an incident that involved a jobless 18 years old young boy Roy Runtubisalemba who is Christian to Ahmad ridwan 23 years old who is Muslim spread quickly to all over Poso. This incident raised strong religious sentiment as occurs when Muslims were fasting in the holy month of Ramadan, while Christians were celebrating the Christmas. Various speculations information spread in the community. Provocation was continued so that the conflict cannot be avoided anymore. Explain further by Ust. Adnan Arsal that:

"that night, many unclear issues spread and were accepted by Muslim emotionally. Then, in the next day December $25^{\text {th }} 1998$ around 14.30 in the afternoon after visiting the victim in hospital, some people came to Toko Lima in Sam Ratulangi Street where Roy and his parents lives to throw wood and stones, From Sam Ratulangi to Yos Sudarso. The focused target was Roy's residence, the one who did the persecution. According to me, this conflict was not happened spontaneously. This was the accumulation of the disappointment of Muslim especially to some wickedness that grows at that time. Therefore, the incident on December 1998 should have handled well without only blaming the fight group but more than that, it needs the sensitivity of the local government, they should have more aspiration so no one blaming each other."

Violence, destruction and vigilante expanded rapidly. There was mass concentration in almost all over Poso. The riot was out of control and spread to places that are considered as an immoral place. These places include hotels linns, discos, massage parlors, billiard, figures and restaurants that sell alcohol. Conflict in Poso continues to religious issues and developed to set up the hatred and killing different religion people.

The development of radical ideology particularly in Muslim group was very quick because of the symbiosis mutualism which occurred since the time of communal conflict. Muslim in Poso is really welcome to the arrival of 'Jihadis" because they came to strengthen Muslim in Poso. More than that, Muslim in Poso received new spirit with the ideological that allow them to fight the Non Muslim as part of Jihad and the guarantee for Jihad is heaven. 


\subsection{Motif of Radicalism Ideology Transformation in the Acts of Terrorism}

Ideology is a set of full ideas, and beliefs that is systematic in the political, economic, social, cultural and religious. Ideology can be regarded as a comprehensive vision. The main objective behind the ideology is to offer change through normative thought process.

To Muslim in Poso particularly to those who were engaged and become the victim in the conflict, radicalism religious doctrine is an enlightenment and motivation for them, so that was why they welcome the radical group with joy. This is what has been elaborated in the research problem about symbiosis mutualism.

The understanding of the value of religion through religious symbols such as clothing, physical characteristics (beard, turban/ cap etc) to the practice of worship mahdha' and muamalat enlight or color up life of people in Poso since radical group out Poso came to join. Specifically, the understanding of the ideology of radical groups in Poso means "Islam Khifah" or make Islam as a totality in everyday life including the enforcement of Islamic law that govern the Qisas and rekindle the spirit of jihad in an attempt of Islamic caliphate.

The transformation radicalism ideology of Muslim terrorist group in Poso caused by several factors (Khairil, 2011), they are: First, an action of terrorism is one case that had been developed in Indonesia including some conflict in some region as in Poso. The terrorism in Poso was at 20022007 or since the reconciliatory phase or post conflict of Malino declaration.

Second is the terrorism case in Central Sulawesi post conflict in Poso ideologically is different to the terrorism case in other provinces. The basic difference is in the motif. The motif of the terrorism in Central Sulawesi was revenge and "symbiosis mutualism" between radical Islam group that came to Poso and Muslim in Poso who experienced the conflict and need the ideological spirit to build the Jihad spirit.

The revenge of Muslim to the Christian was caused by the conflict that claimed lifes and the property of Muslim. The revenge is getting bigger and released through terror action because Muslim felt the sense of manipulation to protect the Christian behind the conflict. The issue of manipulation behind the conflict resolution occurs because the suspects of the tragedy in 1998-2001 were not revealed.

Third, the target was not only the group of individual Christian but to each symbol of religious and police officer/apparatus. The terrorism has transformed into an action of terror not only for the Christian but the police officer and civilian. The action of terror they did was shooting the apparatus, resistance, or even robbery. There are four transformation process of the ideology of radical group in Poso:

\section{The Deconstruction Qisas Ideology to Revenge Law}

The violence of Muslims post-conflict in Poso was gaining legitimacy through the arguments of Al-Qur'an that relevance to the violence in Poso. This is one spirit ideology for Muslims in Poso. One of the legitimacy of violence or acts of revenge that has justification ideology is about qisas. This was revealed by Ust. Hasanuddin, a former convicted terrorist:

It will be very hard to discuss a thing if we have different point of view. We were accused by the rules made by men while we act in accordance with the laws of Allah that is Islamic law. In the Shari'a explained that "whoever does not judge by what Allah has revealed then it is those who are the wrongdoers ". Christians have done injustice against Muslims in Poso and ironically it is automatically erased just because of Malino Declaration. This is the law of man but for the God Almighty it is not. In Islamic law "Al-Anfu Bil Anfi Wal Uzunu Bil Uzuni, wannapsu bin napsi, nose for nose, ear for ear, and life for life. This is the qisas and this is the rule of Allah. The problem is this county is not obey to the rule of Allah but the rules deliberately created by kuffar.

The essence of the law of qisas in Islam provides the right to those who are aggrieved to revenge equally. The word qisas interpreted as equitable retaliation that is murder for murder, wounding for wounding, and beheading for beheading.

Qisas is derived from the word "qashasha" which means to cut off, or is derived from the word "aqasha" which means to follow, follows the actions of criminals for the same retaliation from his actions. While qisas is literally means fair or equal. The meaning of Qisas in syar'i (Ratih, Sari, Arnandi, Bawono, \& Ria Huriah, 2008) is killing people who committed the murder because this is the punishment that is proportionate. Therefore, it can be formulated that qisas is the same consequences applied to someone whose loss someone's' life or limb injure or eliminate the others.

Qisas indicates that the penalty itself has justice because it provides the equality to the executants. If someone is killed the killer has to be killed, so that everyone is satisfied with the provisions of the Qisas. One of the arguments of Al-Qur'an that explains about qisas is in Surah Al-Maidah verse 45 :

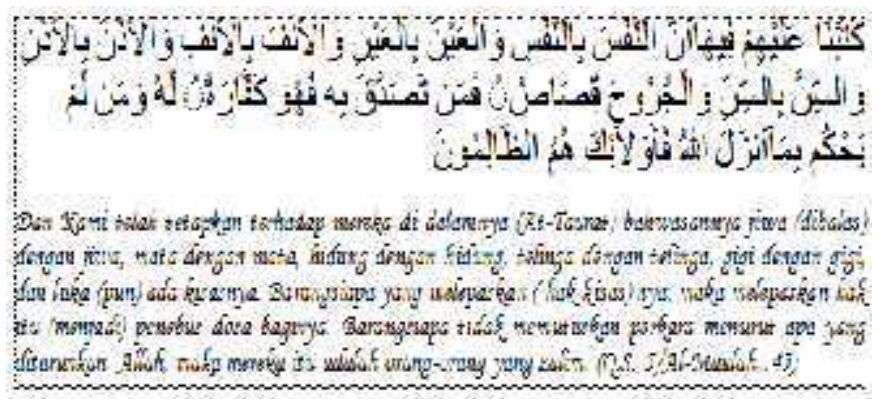


" as we ordained for them therein a life for life, and eye for an eye, a nose for a nose, an ear for an ear, a tooth for a tooth, and for wounds is legal retribution. But whoever gives (up his right as) charity, it is an expiation for him. And whoever does not judge by what Allah has revealed - then it is those who are the wrongdoers"

Qisas is constructed in the form of violence committed in Poso. Qisas is a legitimacy or justification for acts of violence committed by Muslims post conflict in Poso. The meaning of qisas is to "justify" an act of revenge caused by various murder cases such as mutilation, shootings and other acts of revenge. One form of the implementation of qisas by Muslim in Poso was the murder and mutilation of three Christian high school students in Poso on October 29, 2005. Tomo or known as Wiwin Kalahe, as one of the accused and convicted terrorist in this case said:

I confess that I did the murder and the mutilation. Before this incident I and my friends got tausiyah explained that what we will do was for revenge and justice. At that time, I cut the head of one of the student and put it inside plastic bag then placed it in a backpack. Then, we put the heads in houses of Christian so they know and fell what we feel.

This murder by mutilating three Christian female students and the confession of Tomo has proved that the result of the construction of the meaning of qisas as a part of ideological spirit of several terror action in Poso. There were found a piece of letter contain threats to Christian:

\section{* blood for blood \\ * life for life \\ * head for head}

above are the message of our parents that we will never forget and take out of our head. we will always actualize it to jugulate the savages, as the killed, raped, ripped pregnant women. they are very cruel, evil, animal. we will prepare this year to be award of Eid for Muslims.

we are not fool oh the savages. we knew you all afraid to the agreement, you all coward, when we rise, you have to pay it back (Karnavian, 2008).

The motif of revenge that has been constructed into the language of ideology as qisas is becoming a strong legitimacy in conducting the revenge to the Christian. Doctrine of ideology packed with the arguments of AlQuran has made the radical Muslim groups very militant and can do anything in the name of qisas; especially groups of Tanah Runtu Poso. The accumulation of the disappointment of Muslim groups was buried because they all were blend become one unity in the qisas spirit ideology.
2. The Ideology of Jihad Fi Sabilillah Constructed Into Amaliyah, Fa'I, It Spreads Hatred Against The Kuffar And The Thogut

Imam Santoso (Santoso, 2008) states that jihad literally means to mobilize and to devote all the ability in the form of words and actions. In terms of Shariah it means that a Muslim mobilizes and devotes all his ability to fight and establish Islam in order to achieve the pleasure of Allah SWT. Therefore the word of jihad is always accompanied by fi sabilillah to show that jihad of Muslims should be in accordance with the teachings of Islam to gain the pleasure of Allah SWT. The meaning of jihad turns Muslims in Poso to be people who are never give up, very brave and ready to die. This is what happened at 1998-2001 even though at that moment Muslim was in difficult situation. They were in the middle of Poso where the total number of Muslim is minor. The spirit of Jihad turns them (Muslim in Poso) into unbeatable. The meaning of Jihad was constructed based on need and interest post-conflict in Poso, for example, shootings and the murder of prosecutor Ferry Silalahi on June 26, 2004. In such cases, the motif was the actor (the one who shoot) felt "a called" to do "amaliyah" as one form of jihad because the prosecutor insults the aqidah of Muslims.

The spirit of jihad is motivated by three things according to Muslim in Poso especially young Muslim who were in radical group: spiritual, emotional and material. Spiritual motivation is satisfaction of a running command in accordance with the doctrine of ideology. The doctrine of jihad ideology is based on several verses in the Qur'an, such as contained in the letter of An-Nisa verse 95 as follows:

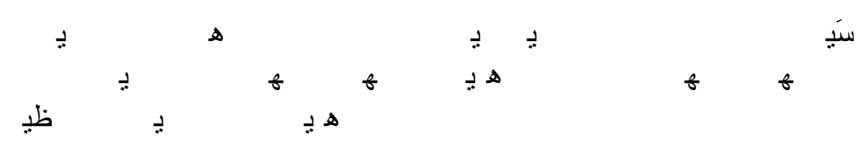

Not equal are those believers remaining (at home) other than the disabled-and the mujahidee. (who strive and fight) in the cause of Allah with their wealth and their lives. Allah has preffered the mujahideen through their wealth and their lives over those who remain (behind), by degrees. And to both Allah has promised the best (reward). But Allah has preferred the mujahideen over those who remain (behind) with a great reward(Q.S.4/Nisa: 95)

The emotional motivation of young Muslim in Poso can be seen through the feeling of revenge to the Christian. For Muslims in Poso, what has been done by the Christian community will not be easily forgiven considering their cruel and heartless behaviors, for instance, the slaughter of children, sexual abuse of women, torture and killing the Muslims. 
Material factors also become part of the spirit of radical groups. Material factor is a motivation that would allow them to take the property of "infidels". The foundation of this action is $f \mathrm{a}^{\prime} I$ or taking the possession of the infidels for jihad or quonimah taking the spoils of war. The main point of Jihad of the radical group in Poso is to fight the Christian. Specifically, Jihad is an effort of Muslim to fight the infidels for Allah.

The spirit ideology through doctrine of jihad is keywords to stir Muslim in Poso to do every action with several motifs, whether its revenge, material motif, or even terror motif. The spirit of jihad that has been embedded in the hearts of most of the residents of Poso will continue to be waged in an effort to actualize Islamic caliphate.

Jihad is generally interpreted as an effort of Muslim to defend and to uphold the Islamic faith, especially in situations of war or conflict. Conflict in Poso has been interpreted as a field of jihad for Muslims to defend the Islamic Aqeedah.

A fact which cannot be denied that not all Muslims in Poso believe that conflict in Poso is jihad for Muslims. Nevertheless, the conflict has been socially constructed and has set the spirit of Islam, not only Muslim in Poso but out of Poso who came to help their Muslim fellow because the number of Muslims was relatively smaller compared to the Christian.

The meaning of jihad is "holy war" heaven as the assurance for the syuhada. The interpretation of the meaning of jihad is constructed by Muslims in Poso through references obtained from the radical Muslim groups. The doctrine becomes power for Muslims. Several meaning of jihad as a result of the construction of a radical group in conflict Poso to post-conflict can be elaborated as follows:

- Jihad is a war against Christians in the Poso conflict.

- Jihad is a revenge that must be accepted by Christian groups for what they had done to Muslims both during conflict and post-conflict.

- Jihad is amaliyah to define targets that will become victim for certain reasons based on the Qur'an and Sunnah.

- Jihad is the enforcement of Islamic law and the rejection of the law other than Islamic law.

- Jihad is to establish the Khilafah Islamiyah.

The meaning of jihad fi sabilillah that were constructed by the radical Muslim group leads them to fight back the Christian in Poso. Jihad also leads Muslim in Poso to perform terror action as a protest to the government that they are not in accordance with the law of Islam. At the end, jihad fi sabilillah brought radical Muslim in Poso as a group of terrorist uses any means to achieve the goal.
3. The Establisment of Islamic Shari'a through the Khilafah Islamiyah that were Constructed as the Resistance and the Rejection Against the Law of 1945 and Pancasila.

The existence of various radical Muslim groups in Indonesia actually has a common desire and a common goal that is to uphold the Islamic law in Indonesia. The desire of upholding the Islamic law is purposed by Enforcement of Islamic Law Preparation Committee (KPPSI). This is just one out of many organizations that desire the establisment of Islamic Shari'a.

There are several reasons that underlie the aspirations of the enforcement of Islamic law in Indonesia they are: First, be a devout Muslim or a true Muslim that make the values of Islam as a totality in everyday life. A true Muslim is a Muslim who refers to Shari'a rules in Islam. Second, the number of the majority of Muslims in Indonesia is a strong reason that the aspiration fought by Muslim is shari'a Islam. Third, law in Indonesia is made by the rule of infidels according to the radical group.

Radical group considers that they only have one choice in their life. It is to keep trying and keep socializing to realize the ideals to uphold Islamic low. The enforcement of Islamic law for Muslim communities in Poso in particular those that are the real radical group is an effort to socialize or even to realize the enforcement of shari'a Islam through hatred doctrine to the Christian. The only source of the shari'a Islam is on the Qur'an and Sunnah, we are not allowed to obey out of Qur'an and Sunnah.

The definition of the enforcement of Islam low leads Muslim in Poso to do murder by shooting, bombing and mutilation as a form of qisas of syariar. In addition, the robbery or spoil as fa'i of war is also based on the rule of Islamic law. More extreme level explains that the meaning of doctrine of the enforcement of Islamic shari'a is rejecting any torm of thaghut or Evil which means a practice of not worship to Allah including all applicable laws in Indonesia, and the 1945 Constitution and Pancasila.

\section{Conclusion}

Based on the description of the results and findings of the research, it can be concluded as follows:

1) The existence of the ideology of radical terrorist groups in Central Sulawesi region especially in Poso is the effect of a prolonged religious conflict. The arrival of radical Muslim group to help Muslim in Poso become an interaction space to create the ideology of radicalism as "symbiosis mutualism" between Muslims in Poso and radical Muslim groups outside Poso.

2) The transformation process of the symbolic meaning of radicalism committed in action of terrorism can be divided into three forms meaning: first is the meaning of qisas that has been constructed as an effort of revenge in many kinds of murder as the Christian did 
to the Muslim in Poso. Second, the meaning of jihad fi sabilillah that has been constructed through the understanding of every form of fight and terror action to the Christian and to the apparatus that is contrary to the principles of justice and Islamic law. Third, the enforcement of Islamic Shari'a and Islamic caliphate constructed as efforts to deny any form of law that is not sourced in Qaeda and Islamic law and fight for the Khalifah Islamiyah is a way of enforcing the Islamic low.

\section{References}

Karnavian, T. (2008). Indonesian Top Secret; Membongkar

Konflik Poso. Jakarta: Gramedia Pustaka Utama. Khairil, M. (2011). Konstruksi Makna Dan Perilaku Komunikasi Terpidana Kelompok Teroris (Studi Kasus Terpidana Aksi Teror Pasca Konflik Poso di Sulawesi Tengah). Padjadjaran University.

Khairil, M., Emrizal, Razman, Rizal, M., Ramli, Z., \& Arifin, K. (2017). Understanding Terrorism Based On Radicalism Idea In Order To Avoid Instability For Achieving Environmental Peace And Justice The Sustainable Development Goals (SDGs). Journal of Food, Agriculture \& Environment, 15(I), 48-51.

Mulyana, D. (2008). Metodologi Penelitian Kualitatif (Paradigma Baru Ilmu Komunikasi dan Ilmu Sosial Lainnya). Bandung: Remaja Rosdakarya.

Nainggolan, P. P. (2002). Terorisme dan Tata Dunia Baru. Jakarta: Tiga Putra Utama.

Nata, H. A. (2001). Peta Kerangka Pemikiran Islam Di Indonesia. Jakarta: Raja Grafindo Persada.

Purwanto, H. W. (2007). Menggapai Damai di Poso. Jakarta: Cipta Mandiri Bangsa.

Rakhmat, J. (2000). Metode Penelitian Komunikasi. Bandung: Remaja Rosdakarya.

Ratih, N. D., Sari, R. F., Arnandi, F., Bawono, V. S., \& Ria Huriah. (2008). Hukum Qishash. Retrieved January 7, 2011, from http://tafany.wordpress.com/2008/06/05/hukumqishash/

Rubaidi, A. (2010). Radikalisme Islam, Nahdlatul Ulama; Masa Depan Moderatisme Islam di Indonesia. Yogyakarta: Logung Pustaka.

Santoso, I. (2008). Jihad Jalan Kami. Retrieved January 8, 2017, from http://www.dakwatuna.com/2008/jihadjalan-kami/

Yin, R. K. (1996). Studi Kasus: Desain dan Metode. Jakarta: Raja Grafindo Persada.

Zainuddin, S. (2008). Pemberdayaan Masyarakat Melalui Pengembangan Model Komunikasi Berbasis Agama dan Budaya Pasca Konflik Poso. PERDAMAIAN, (Agustus). 